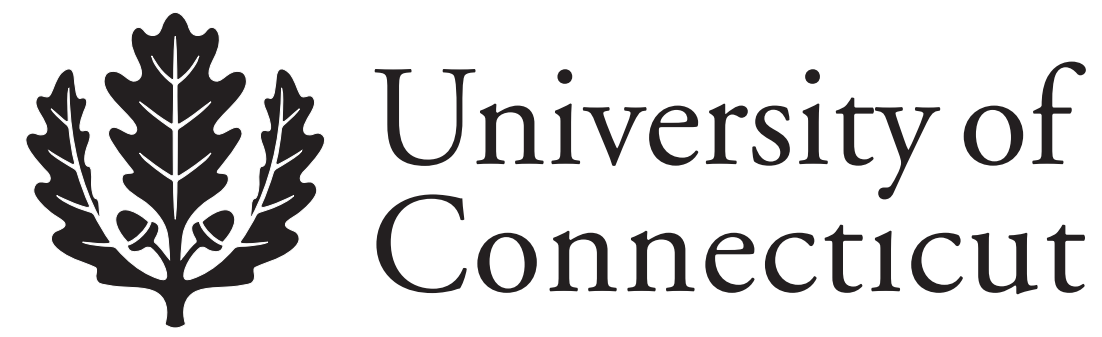

Department of Economics Working Paper Series

Convergence Patterns in Financial Development: Evidence from Club Convergence

Nicholas Apergis

University of Piraeus

Christina Christou

University of Piraeus

Stephen M. Miller

University of Connecticut and University of Nevada, Las Vegas

Working Paper 2010-34

December 2010

341 Mansfield Road, Unit 1063

Storrs, CT 06269-1063

Phone: (860) 486-3022

Fax: (860) 486-4463

http://www.econ.uconn.edu/

This working paper is indexed on RePEc, http://repec.org/ 


\begin{abstract}
This paper analyzes the degree of convergence of financial development for a panel of 50 countries. We apply the methodology of Phillips and Sul (2007) to various financial development indicators to assess the existence of convergence clubs. We consider nine such indicators that various researchers use to proxy for the degree of financial development in countries. Overall, the results do not support the hypothesis that all countries converge to a single equilibrium state in financial development. Nevertheless, strong evidence exists of club convergence. Countries demonstrate a high degree of convergence in the sense that they form only two or three converging clubs, depending on the measure of financial development used. We then apply the Phillip-Sul method to per capita output and also find strong evidence of seven distinct convergence clubs in per capita output. Finally, we compare the various convergence clubs associated with financial development indicators to those clubs for per capita output. We conclude that strong evidence supports the correspondence between the convergence clubs for financial development and those for per capita output.
\end{abstract}

Journal of Economic Literature Classification: F43, F32, G21, C33

Keywords: economic growth, financial development, convergence clustering approach, financial indicators 


\section{Convergence Patterns in Financial Development: Evidence from Club Convergence}

\section{Introduction}

Neoclassical growth theory (e.g., Solow 1956, Swan 1956) implies that real GDP per capita should converge over time, once one incorporates differences in economic structure such as population growth rates, savings rates, depreciation rates, and so on. Researchers have pursued various avenues to alter the structure of the simple Solow-Swan model to make the theory better approximate the data. ${ }^{1}$ For example, Mankiw et al. (1992) introduce a role for human capital and report that the modified model provides a much better fit for the data. Other authors argue that countries do converge in per capita real GDP, but only within clubs of countries with similar characteristics (Quah 1993, 1996, 1997).

The seminal paper of Solow (1956) on the neoclassical growth model led to a continuous flow of both theoretical and applied studies that investigate the issue of income convergence. The measurement and assessment of convergence confronts the researcher with numerous conceptual and statistical problems. The literature contains several notions of convergence and researchers use different econometric methodologies to test for them. Although much of empirical work exists, the convergence debate remains far from a resolved issue.

The actual data confront researches on all sides of the debate with the fact that real income per capita diverges across countries. ${ }^{2}$ What remains unclear, however, is what factors prevent real incomes from converging across countries. Researchers have examined a vast array of determinants to discover which of those factors may erect barriers to convergence. One factor

\footnotetext{
${ }^{1}$ The proponents of endogenous growth models reject the implied convergence of the neoclassical growth model, arguing that real GDP per capita can diverge forever (e.g., Romer 1986, Jones 1995).

2 The development of the Penn World tables (PWT) data set provided the necessary macroeconomic data that facilitated the explosion in the empirical tests of the convergence hypothesis.
} 
that receives much attention is the level of financial development. That is, researchers over the last twenty years have included financial development as a potential factor both for the determination of economic development and for the explanation of the lack of income convergence.

This paper assesses whether financial development can help to explain income convergence among some groups of countries while at the same time, help to explain the income divergence among other groups of countries. Assuming that financial development proves an important precursor for economic development, then income divergence (convergence) among groups of countries may reflect the divergence (convergence) of financial development between these groups of countries. To this end, we examine whether the development of, or lack thereof, financial intermediation and financial markets provides potential explanation for income divergence. That is, if the development of the financial sector converges across countries, whereas income diverges at the same time, then the possibilities for this factor to explain income divergence diminish. Otherwise, the development of the financial sector may offer an important explanation for continuing income inequality. More specifically, we use a new methodology developed by Philips and Sul (2007) to form convergence clubs. We determine convergence clubs for real GDP per capita and investment to GDP as well as for nine alternative measures of financial development. Then we test to see if the convergence clubs for real GDP per capita and investment to GDP correlate with the convergence clubs for the alternative measures of financial development.

We organize the rest of the paper as follows: Section 2 reviews some of the relevant and important literature. Section 3 describes the econometric methodology, while Section 4 describes the variables that we use to capture the development of the financial sector. Section 5 reports the 
empirical results, while Section 6 performs some robustness tests. Finally, Section 7 concludes the paper and provides suggestions for further research.

\section{Literature Review}

We divide our review of the literature into several parts. First, we briefly discuss the major research efforts on $\beta$ - and $\sigma$-convergence as well as the cointegration view of convergence. Third, we review some important research on the relationship between financial development and economic growth.

\section{$2.1 \quad \beta$-Convergence}

Initial empirical tests of the convergence hypothesis fell into the category of $\beta$-convergence tests, where researchers estimated the growth rate of per capita real income on an initial value of real per capita income with or without other conditioning variables. Without other variables, the test considered absolute convergence, whereas with conditioning variables, the test examined conditional convergence. The regressions used to test for beta convergence, generally speaking, adopt a log-linearized solution of a non-stochastic neoclassical growth model (or its augmented versions) with an added error term. Since neoclassical growth theories show the tendency of a specific country's output to converge to its own steady state under specific assumptions, beta convergence provides a suitable test for convergence within an economy.

Barro and Sala-i-Martin (1992) examine income convergence, through a cross-section methodology for 92 countries. Their results indicate the presence of convergence only if the determinant factors of the steady-state income remain constant (conditional convergence). In another important study, Mankiw et al. (1992) also use a cross-section methodology for 98 countries and support conditional convergence, controlling for population growth and capital accumulation. Islam (1995) employs panel estimation techniques to test for the presence of 
convergence in terms of per capita real income. He uses the same data set as Mankiw et al. (1992) and he supports conditional convergence for per capita real income. Nevertheless, he criticizes the significance of conditional convergence, because it shows that each country converges to different levels of steady-state income.

Lee et al. (1997) develop a stochastic Solow-Swan growth model to test for the presence of convergence for per capita income with data from 102 countries, developing four different methods for testing $\beta$-convergence. When they relax the homogeneity assumptions involved in the traditional cross-section and panel-data estimation approaches, they find that the speed of convergence increases dramatically, but the precision of the estimates deteriorates significantly. Their results imply significant differences in the steady-state growth rates across countries. Additionally, they argue that researches should explicitly consider the heterogeneity across countries in the steady state to avoid biases in the tests for convergence. But as just mentioned, the precision of their estimates deteriorates dramatically when considering such heterogeneities. Nonetheless, the authors conclude that growth of technology differs across countries, although OECD countries experience higher technical growth with lower dispersion, on average. Difference in the growth of technology, given the cross-country heterogeneity, implies divergence, and not convergence, among countries. Blinder and Pesaran (1999) question the adequacy of beta convergence regressions. They show that beta convergence when studying the growth path of a given economy towards its own steady state can collapse under stochastic technological progress. Durlauf et al. (2005) point out that a negative coefficient (beta) on initial income in a cross-section framework can simply imply that economies converge to their own different steady states. Finally, Pesaran (2006) argues that by definition, beta convergence refers 
to convergence within an economy. Despite these arguments, most empirical studies analyze the cross-country output dynamics by testing for beta convergence using cross-section data.

\section{$2.2 \sigma$-Convergence}

According to $\sigma$-convergence, a group of economies converges if the cross section variance of the per capita output decline across time. Friedman (1992) and, more recently, Cannon and Duck (2000) propose regression specifications to test for $\sigma$-convergence. Bliss $(1999,2000)$ argues, however, that the underlying assumption of an evolving data distribution introduces difficulties in the interpretation of the test distribution under the null. Moreover, the rejection of the $\sigma$ convergence hypothesis does not necessarily mean that economies do not converge. The presence of transitional dynamics in the data can lead to the rejection of the null hypothesis of $\sigma$ convergence.

Critics of $\beta$-convergence argue that it provides a necessary, but not sufficient, ingredient for observing reductions in real per capita income dispersion (Friedman 1992, Quah 1993). If countries converge to a common equilibrium with shared global technologies and identical internal structures, then the dispersion of income should disappear in the long-run as all countries converge to the same real per capita income. If, however, countries converge to convergence clubs or to their own unique equilibrium, the dispersion of real per capita income will not approach zero. Moreover, in the latter case of country specific equilibrium, the movements of the dispersion will depend on the initial distribution of real per capita incomes relative to their final long-run outcomes. Quah $(1993,1996,1997)$ examines his hypothesis of convergence clubs, viewing the evolution over time of the grouping of real per capita incomes.

Durlauf and Johnson (1995) dismiss the frequently used linear model that studies crosscountry economic behavior in favor of multiple regimes, using a data set of 121 countries. They 
reject the hypothesis of convergence in real per capita income, while they find evidence for club convergence to multiple steady states.

Canova (1999) proposes a new technique for grouping converging countries in terms of real per capita income. His methodology implies that countries exhibit multiple steady states for real per capita income. He empirically tests for convergence across two samples -- data from 144 European regions and 21 OECD countries. He finds that the steady-state distribution of income for European regions clusters around four different nodes, while that for the OECD countries clusters around two different nodes.

Pesaran (2006) proposes a general probabilistic definition of convergence and uses a pairwise approach to test for output convergence across countries, using output data from the Penn World Tables. His method indicates no convergence in terms of real per capita income. By contrast, he finds convergence in real per capita income growth rates. He argues that these results may reflect the following: although technology spreads widely across countries, other important country specific factors exist that prevent output between countries from converging.

Grier and Grier (2007) consider which factors lead per capita income to diverge. Their sample employs data from 90 countries, while their results provide strong evidence of income divergence across countries. They also argue that researchers should include new additional possible determinants of income divergence, as the traditional factors from the neoclassical growth model cannot explain real per capita income divergence, because these traditional factors converge across countries.

Phillips and Sul (2003) argue that cross-section divergence is possibly a transient phenomenon, since economies may exhibit transitional divergence on their way toward a common steady state. They make use of a new methodology to test for club convergence. They 
examine three different samples for convergence in per capita real income. The first sample employs data from 48 U.S. states, the second sample, data from 18 western OECD countries, and the third sample, data from 152 countries reported in the Penn World Tables. Their results for the U.S. sample indicate that the transition paths for every state appear to converge. The results for the OECD sample indicate divergence in terms of per capita income until World War II. Around 1950, however, this pattern changed and the transition paths of per capita income appear to converge. Finally, the results from the Penn World Tables sample indicate that although per capita income diverges across countries, strong evidence exists for converging subgroups (i.e., club convergence).

\subsection{Cointegration View of Convergence}

In the empirical growth literature, the majority of empirical studies refer to convergence as the tendency for the output gap to narrow across countries. In this literature, Bernard and Durlauf (1995, 1996) provide the first formal definition of cross-country convergence. Their statistical definition states that two countries converge if their long-term forecasts are equal. According to their definition, two countries converge, if their output gap is a zero mean stationary process. Given the empirical regularity that output series are usually I(1) processes, researchers can test for convergence using cointegration or unit-root procedures. They note that cointegration (or unit-root) tests are appropriate for testing convergence if countries are near their steady state. That is, if outputs are converging but are not near their steady state, cointegration (or unit-root) tests tend to reject the null of convergence. Although their results indicate that per capita real incomes do not converge, they find a group of long-run factors that jointly determine output growth for the countries under investigation. Evans (1996) applies an alternative method that 
uses the cross-country variances of per capita real income, using a sample of 15 countries. His results indicate that income reverts to a common trend.

A number of serious drawbacks exist with the use of cointegration and unit-root tests to test for output convergence. First, these tests fail to detect convergence when multiple equilibria exist. In the growth literature, theoretical and empirical evidence exists to support club convergence. In Azariadis and Drazen's (1990) theoretical growth model, multiple steady-state equilibria can occur. Hobijn and Frances (2000) as well as Durlauf and Johnson (1995) provide empirical to support convergence clubs.

Second, if the countries converge but the available data come from a time period of transitional dynamics, cointegration and unit-root tests may not 'catch' the convergence.

Third, suppose that two countries do converge to the same steady state and that they are also near the steady state. If output data available to the researcher combines steady-state and transitional data (which is a realistic scenario given that the Summers-Heston data spans at most a period of 57 years), then empirical testing for convergence using cointegration and unit-roots tests may lead to misleading results. Given the usual sample sizes in empirical studies, it is unlikely that the data only contain countries near their steady states. In other words, testing for convergence requires a specification that consistently models both transitional dynamics and long run behavior. Unfortunately, standard testing methodologies for output convergence fail to accommodate both regularities and, thus, they do not provide suitable tests for real economic convergence. Durlauf et al. (2005) in an excellent survey argue that growth econometrics is still in its infancy and that researchers need to develop new econometric methodologies for testing the convergence hypothesis. That is, new methods must evaluate the transitional dynamics of growth paths as well as the long run convergence across economies. 


\subsection{Growth and Financial Development}

Many empirical investigations examine the relationship between the growth of income and financial development. Goldsmith (1969) considers whether financial development affects economic growth. He uses the ratio of the value of financial intermediary assets to GNP as a measure for financial development. His results indicate that financial development closely associates with economic development.

Jung (1986) investigates international evidence on the causal relationship between financial development and economic growth, employing Granger temporal causality. He uses the ratio of currency to the narrow definition of money (M1) (the currency ratio) and the ratio of M2 to nominal GDP (or in some cases to nominal GNP) to proxy for financial development. His results provide moderate empirical underpinning to the theory of Patrick (1966), where in lessdeveloped economies supply-leading causality patterns dominate demand-following causality patterns. $^{3}$

King and Levine (1993) consider whether higher levels of financial development promote economic growth. To measure the services provided by financial intermediaries, they construct four different variables of "financial depth," -- the sum of currency outside the banking system and demand and interest-bearing liabilities of banks and nonbank financial intermediaries to GDP, the ratio of deposit money bank domestic assets to the sum of deposit money bank domestic assets and central bank domestic assets, the ratio of claims on the nonfinancial private

\footnotetext{
${ }^{3}$ Patrick (1966) explains the relationship between financial development and economic growth through two different patterns -- supply-leading and demand-following. More specifically, supply-leading patterns occur when the financial development provides the necessary tools to facilitate economic growth, implying that financial development precedes economic development. By contrast, demand-following patterns occur when economic development leads financial development. He develops the idea that supply-leading patterns occur in the initial stages of economic development when economic activity rises creating a feedback effect onto the financial sector through the increased demand for financial services. Demand-following patterns eventually dominate supply-leading patterns, as economic development proceeds.
} 
sector to total domestic credit (excluding credit to money banks), and the ratio of claims on the nonfinancial private sector to GDP. The last two variables measure the distribution of domestic assets. The intuition underlying these measures is as follows: a financial system that allocates funds to the government or to state-owned enterprises as opposed to the private sector may not provide the effective financial services to facilitate economic growth. King and Levine (1993) use two different econometric methodologies to examine the relationship between financial and economic development -- cross-country analysis and pooled cross-country time-series analysis. Their results indicate that financial development strongly and positively correlates with economic growth.

Atje and Jovanovic (1993) use cross-country analysis to examine whether financial development affects the level and/or the growth rate of economic development. They construct two different measures of financial development -- a financial intermediation measure that equals the ratio of credit extended by private and government banks to GDP and a financial markets development measure that equals the ratio of the annual value of all stock market trades to GDP. Their results indicate that stock markets affect economic development, whereas banking lending does not.

Levine and Zervos (1996) explore whether financial development affects economic development. To cover the possible influences of the financial systems as possible, they use numerous variables to measure financial development: the market capitalization ratio, the turnover ratio, the value traded ratio, intercept terms from CAPM and APT models, the volatility of stock returns, and, finally, the value of loans made by banks to private enterprises divided by GDP. Their results show that stock market liquidity and banking development positively and robustly correlate with current and future rates of economic growth. Furthermore, they find that 
stock market liquidity, international capital market integration, or stock return volatility do not hinder long-run growth. Finally, they report that stock market capitalization, stock market volatility, and capital market integration insignificantly affect economic growth.

Demetriades and Hussein (1996) use time-series techniques to examine the causality between financial development and real GDP. They use two different measures of financial development: the ratio of bank deposit liabilities to nominal GDP and the ratio of bank claims on the private sector to nominal GDP. Their results support bidirectional causality between financial and economic development.

Rajan and Zingales (1998) examine whether financial development affects industrial growth. To this end, they use two different measures of financial development: the ratio of domestic credit plus market capitalization to GDP and the accounting standards of each country. Their results show that financial development positively affects economic growth, by reducing the costs of external finance to financially dependent enterprises.

Levine et al. (1999) consider the possible causality between economic and financial development, while they also consider those potential factors that differentiate the degree of financial development across countries. They use two different econometric methodologies, pure cross-country and panel-data (GMM) methods, and three different measures of financial development: the sum of currency outside the banking system and demand and interest-bearing liabilities of banks and nonbank financial intermediaries to GDP, the ratio of the sum of deposit money bank domestic assets and central bank domestic assets to GDP, and the ratio of claims on the nonfinancial private sector to GDP. The results imply that financial development exerts a significant effect on economic growth. 
Beck et al. (2000) research the causal effects of financial development on real per capita GDP growth. They employ two different econometric methods in their study -- cross-county analysis of a 63 country sample from 1960 and 1995 and panel-data analysis of the same 63country sample with data averaged over each of the seven 5-year sub-periods between 1960 and 1995. They use three variables related to banking development: private credit issued by financial intermediaries divided by GDP, liquid liabilities of the financial system divided by GDP, and the ratio of commercial bank domestic assets divided by the sum of commercial bank and central bank domestic assets. Their results indicate that financial development positively and robustly cause real per capita GDP growth as well as the productivity of per capita GDP growth. They conclude that a better functioning financial system improves asset allocation and accelerates total productivity growth and, eventually, long-run economic growth.

Aghion et al. (2004) investigate empirically whether a country will converge to the growth rate of the world technological frontier when it surpasses a critical level of financial development and whether financial development exerts a positive, but gradually vanishing, effect on steady-state per capita GDP in relation to the frontier. They use, as a measure of financial development, the private credit issued by financial intermediaries divided by GDP. Additionally, they use two alternative measures of financial development to test for the robustness of their results -- liquid liabilities of the financial system divided by GDP and the ratio of commercial bank domestic assets divided by the sum of commercial bank and central bank domestic assets. They find that the likelihood of a country converging to the U.S. growth rate increases along with its financial development. Furthermore, the direct effect of financial intermediation proves insignificant, implying that the effect of financial development on economic growth diminishes. 
They conclude that financial development significantly determines the divergence across countries in terms of real per capita GDP growth.

Finally, Fung (2008) incorporates the interaction of the financial and real economic sectors into a traditional test for convergence to examine whether financial development and economic development converge to or diverge from each other. He employs two different variables as proxies for financial development: credit allocated to the private sector and quasimoney. His results imply that middle-income and high-income countries conditionally converge in both economic and financial development. Additionally, he finds that the relationship between financial development and economic growth strengthens in the early stages of economic development, but diminishes as sustained economic growth occurs.

\section{Methodology}

We begin with a simple premise: if a factor converges across a sample of countries, then it cannot cause the divergence of another factor (i.e., real per capita income) across the same sample of countries. That is, no notion of correlation exists between the factors. In other words, if within a sample of countries a particular variable converges, then that specific variable cannot provoke any differences observed in the same sample of another variable. By contrast, if a variable diverges across a sample of countries, then we cannot say that this variable causes the observed divergence of another variable of this same sample. We cannot, however, exclude this variable as an explanatory factor for this divergence. In other words, in this study, we test the hypothesis of whether financial development measures may cause divergence of real per capita income.

We test our hypothesis in two steps. First, we examine separately each of the possible causal factors, to see if they converge or diverge across our sample. Additionally, we also test 
whether real per capita income converges. Second, because of the econometric methodology that we use (Phillips and Sul, 2007), we can also detect converging subgroups (i.e., club convergence). Thus, we possess an extra opportunity to check our hypothesis on a relative basis. That is, if a financial variable diverges across the whole sample, but converges across several subgroups of the same sample, and real per capita income also converges across several, but not necessarily the same subgroups, we may or may not infer that this financial variable exerts a causal influence on real per capita income. For example, if both variables diverge across the entire sample, what level of subgroup convergence with respect to number of groups and their composition will suggest that the two variables share some correlation? We construct a chisquared test for independence to answer this last question.

\subsection{Econometric Methodology}

Phillips and Sul (2007) propose a new econometric approach for testing the convergence hypothesis and the identification of convergence clubs. Their method uses a nonlinear timevarying factor model and provides the framework for modeling transitional dynamics as well as long run behavior. Furthermore, their methodology is largely statistical in nature so it can be employed to test for convergence in economic variables other than output.

The new methodology adopts the following time varying common factor representation for $y_{i t}$ of country i:

$$
y_{i t}=\delta_{i t} \mu_{t},
$$

where $\mu_{t}$ is a single common component and $\delta_{i t}$ is a time-varying idiosyncratic element that captures the deviation of country $i$ from the common path defined by $\mu_{t}$. Within this framework, all $\mathrm{N}$ economies will converge, at some point in the future, to the steady state, if $\lim _{k \rightarrow \infty} \delta_{i t+k}=\delta$ for all $\mathrm{i}=1,2, \ldots, \mathrm{N}$, irrespective of whether countries are near the steady state or in transition. This is 
important given that the paths to the steady state (or states) across countries can differ significantly.

Since we cannot estimate $\delta_{i t}$ directly from equation (1) due to over-parameterization, Phillips and Sul (2007) eliminate the common component $\mu_{t}$ through rescaling by the panel average:

$$
h_{i t}=\frac{y_{i t}}{\frac{1}{N} \sum_{i=1}^{N} y_{i t}}=\frac{\delta_{i t}}{\frac{1}{N} \sum_{i=1}^{N} \delta_{i t}} .
$$

The relative measure $h_{i t}$ captures the transition path with respect to the panel average. Defining a formal econometric test of convergence as well as an empirical algorithm of defining club convergence requires the following assumption for the semi-parametric form for the timevarying coefficients $\delta_{i t}$ :

$$
\delta_{i t}=\delta_{i}+\sigma_{i t} \xi_{i t}
$$

where $\sigma_{i t}=\frac{\sigma_{i}}{L(t) t^{\alpha}}, \sigma_{i}>0, t \geq 0$, and $\xi_{i t}$ is weakly dependent over $\mathrm{t}$, but iid $(0,1)$ over $\mathrm{i}$. The function $L(t)$ varies slowly, increasing and diverging at infinity. ${ }^{4}$ Under this specific form for $\delta_{i t}$, the null hypothesis of convergence for all $\mathrm{i}$, takes the form: $H_{0}: \delta_{i}=\delta, \alpha \geq 0$ while the alternative hypothesis of non-convergence for some i, takes the form:: $H_{A}: \delta_{i} \neq \delta$ or $\alpha<0$. Phillips and Sul (2007) show that we can test for the null of convergence in the framework of the following regression: ${ }^{5}$

\footnotetext{
${ }^{4}$ In this paper, we set $L(t)=\log (t)$.

${ }^{5}$ Appendix B of Phillips and Sul (2007) reports the analytic proof under the convergence hypothesis for this regression equation.
} 


$$
\log \left(\frac{H_{1}}{H_{t}}\right)-2 \log L(t)=\hat{c}+\hat{b} \log t+\hat{u}_{t}
$$

for $t=[r T],[r T+1], \ldots . ., T$, and $r>0{ }^{6}$. In this regression, $H_{t}=\frac{1}{N} \sum_{i=1}^{N}\left(h_{i t}-1\right)^{2}$ and $\hat{b}=2 \hat{\alpha}$, where $h_{i t}$ is defined in (2) and $\hat{\alpha}$ is the least squares estimate of $\alpha$. Under the null hypothesis of convergence, the dependent variable diverges whether $\alpha>0$, or $\alpha=0$. In this case, we can test the convergence hypothesis by a t-test of the inequality, $\alpha \geq 0$. The t-test statistic follows the standard normal distribution asymptotically and is constructed using a heteroskedasticity and autocorrelation consistent standard error. Phillips and Sul (2007) call the one-sided $t$ test, which is based on $t_{\hat{b}}$, the $\log (t)$ test due to the presence of the $\log (t)$ regressor in (4). ${ }^{7}$

The empirical convergence literature also deals with the possible existence of multiple equilibria. In that case, rejection of the null hypothesis that all countries in the sample converge does not imply the absence of convergence clubs in the panel. In this study, we implement the club convergence and clustering procedure proposed by Phillips and Sul (2007). We summarize that procedure as follows: (1) Order the $\mathrm{N}$ countries according to the value of the final times series; (2) Form all possible core (club) groups $C_{k}$ by selecting the first $k$ highest countries, with $k=2,3, \ldots, N$. Then, test for convergence using the $\log t_{k}$ test within each subgroup of size $k$. Finally, define the core (club) group $C^{*}$ of size $k^{*}$ as the group for which the maximum computed $\log t_{k^{*}}$ statistic occurs, given that all $\log t_{k}$ statistics support the convergence hypothesis; (3) Find all the countries that according to the $\log (t)$ test converge to the same steady state with the core group $C^{*}$, which identifies the first convergence club in the panel. Then, for

\footnotetext{
${ }^{6}$ Following the recommendation of Phillips and Sul (2007), we choose $r$ values in the interval [0.2, 0.3].

${ }^{7}$ The $\log (t)$ test exhibits favorable asymptotic and finite sample properties.
} 
the remaining countries (if any), repeat the procedure in order to determine the next convergence club, if one exists. Finally, terminate the procedure when the remaining economies fail to converge.

Applying the Phillips and Sul (2007) methodology to the various series will place countries into convergence clubs. For example, we derive the convergence clubs for real GDP per capita and for a specific financial development variable, say bank deposits to GDP. Since both variables are categorical, we apply a chi-squared test of independence. The null hypothesis is that the two categorical variables are independent. The alternative hypothesis is that the two variables are not independent. When we can reject the alternative hypothesis, then bank deposits to GDP clubs can help to predict real per capita GDP clubs. In other words, if the financial development variables can help to explain club convergence of real GDP per capita, then we should not find independence between the convergence clubs for the financial development variables with respect to the convergence clubs for real GDP per capita.

The test for independence is given as follows:

$$
\chi^{2}(r-1, c-1)=\sum \frac{\left(O_{r, c}-E_{r, c}\right)^{2}}{E_{r, c}},
$$

where $r$ equals the number of clubs in variable $X$ (e.g., real GDP per capita), $c$ equals the number of clubs in variable $Y$ (e.g., a financial development variable), $O_{r, c}$ equals the observed frequency in row $r$ and column $c, E_{r, c}$ equals the expected frequency in row $r$ and column $c$, and $(r-1, c-1)$ equal the degrees of freedom in the chi-squared statistic.

\section{Data}

To capture the effects of financial sector development on real per capita income, we use data from 50 countries (see Appendix A). In particular, data on real per capita income comes from Penn World Tables 6.2 (in dollars, constant prices of 2000 and Laspeyres series) from 1970 to 
2003. The study uses nine different financial sector development measures, which we divide into two broad, but different, categories according to their informational content. The categories are measures of size and measures of financial market activity. Data comes from the World Bank's Financial Development and Structure Database and spans 1980 to 2003. We further divide the first of the former two categories into two more explicit categories, the relative and absolute size measures. The relative size measures give information on the structure of financial intermediation within an economy, whereas the absolute size measures provide information on the size of the financial intermediation sector relative to the size of the whole economy.

\subsection{Measures of Size of Financial Intermediaries: Relative Size Measures}

\subsubsection{Deposit Money Banks Assets To Central Bank Plus Deposit Money Banks Assets}

The more funds allocated to deposit money banks than to the central bank implies that the financial system proves more efficient and facilitates better economic development.

\subsubsection{Bank Credit to Bank Deposits}

This relative measure of financial intermediation development discloses the part of bank deposits allocated to bank credit. A higher ratio indicates that banks operate efficiently and channel the majority of funds to credit.

\subsection{Measures of Size of Financial Intermediaries: Absolute Size Measures}

\subsubsection{Central Bank Assets to GDP}

This variable shows how large the central bank is relative to GDP. The larger this variable is, the less developed the financial system is. It does not facilitate economic growth.

\subsubsection{Deposit Money Banks Assets to GDP}

The larger the ratio is, the more developed the banking sector is.

\subsubsection{Liquid Liabilities to GDP}


This broader measure of the development of financial intermediation includes data not only from deposit money banks and the central bank but also from other financial institutions. This variable focuses on the liability side of the balance sheets and typically measures financial "depth". It equals the sum of currency and demand and interest-bearing liabilities divided by GDP.

\subsubsection{Bank Deposits to GDP}

This indicator relates only to deposits of banks and does not include any other liabilities or any liability of other financial intermediaries. A larger bank deposits to GDP ratio means that more money passes through the banking system, implying a more developed financial intermediation system.

\subsubsection{Financial System Deposits to GDP}

This variable broadens the prior measure by adding to bank deposits from other financial institutions (see Appendix B).

\subsection{Measures of Activity of Financial Intermediaries}

\subsubsection{Private Credit by Deposit Money Banks to GDP}

This variable measures the funds allocated only from private deposit money banks to the private credit sector. This variable captures only the characteristics of financial development that facilitate economic growth.

\subsubsection{Private Credit by Deposit Money Banks and Other Financial Institutions to GDP}

This variable broadens the prior variable by adding to funds allocated only from private deposit money banks to the private credit sector funds allocated from other private financial institutions.

The fact that the sample period for income does not match that of the financial variables does not affect in a deterministic manner the validity of our inference, since the series do not interact within the method used. Consequently, taking into consideration the asymptotic nature of 
the convergence test, we can determine the countries that see convergence in real income per capita and separately the countries that see convergence in financial development measures .

\section{Empirical Results}

This section reports the findings for convergence and club convergence of real per capita GDP as well as the various financial development measures. We begin by examining real per capita GDP. Table 1 reports the results of the panel convergence methodology for real per capita GDP. The first row reports the result of testing full convergence (i.e., convergence among all sample countries), while rows 2 to 7 display the results of the club clustering procedure.

The results of the convergence test real for per capita income reject the null hypothesis of income convergence, since the point estimate of the $\log (t)$ statistic is -288.270 (critical value of 1.67). Nevertheless, the formation of the five different convergence clubs, where the first includes all developed countries, except New Zealand and the U.S., and of one non-convergent set of countries conform with the results of the related literature. That is, many studies find no absolute convergence for samples that include developed and developing countries, but convergence for samples that include only developed countries.

\subsection{Measures of Financial Intermediaries Size: Relative Size Measures}

\subsubsection{Deposit Money Banks Assets to Central Bank Plus Deposit Money Banks Assets}

Table 2 reports the results for this financial development measure, one of two relative size financial development measures. We reject the null hypothesis of full convergence for this variable at the 5-percent significance level with the $\log (t)$ statistic equal to -2.127 . The results of the club convergence algorithm indicate the presence of two clubs. Forty three out of the fifty countries form the first club, whereas the second club includes only five countries. Cameroon and Niger do not converge at all. As a result, we can speak for virtually a full convergence 
pattern for this variable. This result suggests that convergence exists across most countries with respect to the relative shares of the banking system going to the central bank and the deposit money banks.

While it may appear that the convergence pattern of this measure will not relate to the convergence pattern of real per capita income, we strongly reject the chi-squared test for independence at the one-percent level (See Table 12 below). Hence, this variable may play a role in the convergence of real per capita income into its clubs.

\subsubsection{Bank Credit to Bank Deposits}

Table 3 reports the results for this variable. We reject the null hypothesis of full convergence for this variable at the 5 -percent significance level with the $\log (t)$ statistic equal to -5.778 . The results of the club convergence algorithm, once again, indicate the presence of two clubs with 38 countries in the first club and 11 countries in the second, including Japan. Algeria does not converge at all. Compared to the previous variable, we see more dispersion of countries with more in the second group. Moreover, the 11 countries in the second group appeared in the first group for the prior variable and each country in group two for the prior variable now appear in group one.

We cannot reject the chi-squared test for independence even at the 10-percent significance level (see Table 12 below). Consequently, this variable probably does not play a role in the convergence of real per capita income into its clubs.

\subsection{Measures of Financial Intermediaries Size: Absolute Size Measures}

\subsubsection{Central Bank Assets to GDP}

Table 4 reports the results for this variable. We reject the null hypothesis of full convergence for this variable at the 5-perrcent significance level with the $\log (t)$ statistic equal to -2.904 . Once 
again, we observe two different clubs with $\log (t)$ statistics -1.555 and -0.709 , respectively. Club one includes 33 countries with many developed countries while club two includes 17 countries, including Denmark, Finland, Portugal, and Spain.

We cannot reject the null hypothesis of independence between this variable and real per capita income (see Table 12 below). As a result, this variable probably does not play a role in the convergence of real per capita income into its clubs.

\subsubsection{Deposit Money Banks Assets to GDP}

Table 5 reports the results for this variable. We, once again, reject the null hypothesis of full convergence for this variable at the 5-percent significance level, with the $\log (t)$ statistic equal to -0.371 . Furthermore, the results of the clustering algorithm show three convergent clubs, with $\log (t)$ statistics $-1.581,0.659$ and 1.232 , respectively. The majority of the countries appear in two different convergence clubs (35 in club one and 11 in club two), whereas three countries (Cameroon, Suriname, and Venezuela) form the third convergence club, while Niger falls in an independent divergent club. Additionally, we see only developed countries in the first club.

In this case, we can reject he null hypothesis of independence at the 5-percent significance level (see Table 12 below). Consequently, this variable may play a role in the convergence of real per capita income into its clubs.

\subsubsection{Liquid Liabilities to GDP}

Table 6 reports the results for this variable. We can reject the null hypothesis of full convergence at the 5-percent significance level with the $\log (t)$ statistic equal to -58.685 . The results of the club convergence algorithm indicate the presence of three convergent clubs with $\log (t)$ statistics $0.973,2.970$ and 5.829, respectively. Club one contains 23 countries while clubs two and three 
contain 9 and 17. While Japan does not converge at all, most developed countries appear in the first club, except for Denmark and Finland in club two.

We cannot reject the null hypothesis of independence between this variable and real per capita income even at the 10-percent significance level (see Table 12 below). Thus, this variable probably does not play a role in the convergence of real per capita income into its clubs.

\subsubsection{Bank Deposits to GDP}

Table 7 reports the results for this variable. We reject the null hypothesis of full convergence in this variable at the 5-percent significance level with the $\log (t)$ statistic equal to -49.250 . The results of the club convergence algorithm indicate the presence of four convergent clubs with $\log (t)$ statistics equal to $2.317,1.354,1.148$ and 2.387 , respectively. Club one contains 3 countries while clubs two, three, and four contain 17, 18, and 11. While Japan forms an independent diverging club. The developed countries spread out across the first three clubs with Canada and Switzerland in club one and Denmark, Finland, and Italy in club three.

We reject the null hypothesis of independence at the 10-percent level (see Table 12 below). As a result, this financial measure may play a role in the convergence of real per capita income into its clubs.

\subsubsection{Financial System Deposits to GDP}

Although this variable generalizes the previous variable, the results prove quite different. Table 8 reports the results for this variable. We reject the null hypothesis of full convergence at the 5percent significance level with the $\log (t)$ statistic being equal to -52.154 . In this case, we observe the formation of two main clubs with 20 countries in club one, including most of the developed countries, and 24 countries in club two, including Denmark, Finland, and Italy. An additional club includes five countries. Japan again does not join any club. 
We do reject the null hypothesis of independence for this variable at the 5-percent significance level (see Table 12 below). Consequently, this variable may play a role in the convergence of real per capita income into its clubs.

\subsection{Measures of Activity of Financial Intermediaries}

\subsubsection{Private Credit by Deposit Money Banks to GDP}

This variable provides the first of two measures of the credit creation activity of financial intermediaries. The results differ somewhat to those before. Table 9 reports the results for this variable. We reject the null hypothesis of full convergence for this variable at the 5-percent significance level with the $\log (t)$ statistic equal to -15.756 . The empirical findings identify four different convergence clubs with a quite similar distribution to that of per capita income. For example, all developed countries enter club one.

We do reject the null hypothesis of independence for this variable at the 1-percent significance level (see Table 12 below). Consequently, this variable may play a role in the convergence of real per capita income into its clubs.

\subsubsection{Private Credit by Deposit Money Banks and Other Financial Institutions to GDP}

This variable provides the second measure of the credit creation activity of financial intermediaries. Table 10 reports the results for this variable. We reject the null hypothesis of full convergence at the 5-percent significance level with the $\log (t)$ statistic equal to -34.568 . The results show six distinct convergence clubs with the $\log (t)$ statistics of $-1.309,1.404,-1.455$, $0.856,0.150$ and 6.256 , respectively. The distribution of countries for this variable also is similar to the distribution in clubs for real per capita income. For example, nearly all developed countries fall into club one. Finland, the exception, falls into club two. 
We do reject the null hypothesis of independence for this variable at the 1-percent significance level (see Table 12 below). Consequently, this variable may play a role in the convergence of real per capita income into its clubs.

\section{Robustness Tests}

This section considers a robust determinant of the growth rate of real GDP per capita, investment to GDP (Levine and Renelt, 1992). We consider the number of convergence clubs for investment to GDP and then test for the independence of the real per capita income and investment to GDP clubs. Finally, we also test the independence of investment to GDP and the measures of financial development. We use gross fixed capital formation to GDP in current prices and in US dollars. This data comes from the International Financial Statistics database. We measure the series in logarithms.

Economists, attempting to explore the economic success or failure, argue that fixed capital formation or investment plays the key role in determining economic growth. In particular, economies that grow quickly pursue investment projects as a significant fraction of their GDP. This explanation relies primarily on the neoclassical growth model (Solow, 1956; Swan, 1956). Fixed capital formation also closely relates to technological progress and changes in productivity (Lucas, 1988; Blanchard and Fischer, 1989; Uzawa, 1996). The empirical analysis mostly provides results against the significance of such a macroeconomic variable. More specifically, Easterly et al. (1993), Easterly and Levine (2001), and Doppelhoffer et al. (2004) show that investment rates do not move much across decades, while growth rates do, suggesting that investment does not determine growth. These authors, however, argue that what really matters is not the overall level of investment, but its quality and efficiency. Nevertheless, a handful of empirical studies reach the conclusion that capital formation determines an economy's growth 
rate (De Long and Summers, 1991 and 1992; Levine and Renelt, 1992; Mankiw et al., 1992). They provide empirical results supportive to the argument that fixed capital formation seems to determine the rate of an economy's economic growth. Rodrik (1994) also reaches the same conclusions in an open economy framework in which a higher rate of fixed capital formation leads to increased imports and higher growth as well, which both lead to higher exports.

Table 11 reports the results for this variable. We reject the null hypothesis of full convergence for the variable of the share of investment to GDP at the 5-percent significance level with the $\log (t)$ statistic being equal to -33.663 . The results of the club convergence algorithm indicate the presence of three clubs with $\log (t)$ statistics of $-1.246,3.622$, and 4.617 . All developed countries appear in club one.

We do reject the null hypothesis of independence for this variable at the 5-percent significance level (see Table 12 below). Consequently, this variable may play a role in the convergence of real per capita income into its clubs.

As the final test, we consider the independence of the clubs for investment to GDP and the various measures of financial development. Table 12 reports the findings. For the first three variables -- deposit money banks assets to central bank and deposit money banks assets, bank credit to bank deposits, and central bank assets to GDP, we cannot reject the null hypothesis of independence at even the 10-percent level. That is, these financial development measures may not to play a role in the convergence of investment to GDP into its clubs. For the remaining financial development measures -- deposit money banks assets to GDP, liquid liabilities to GDP, bank deposits to GDP, financial system deposits to GDP, private credit by deposit money banks to GDP, and private credit by deposit money banks and other financial institutions to GDP, we reject the null hypothesis of independence at the one-, five- or ten-percent levels. That is, these 
financial development measures may play a role in the convergence of investment to GDP into its clubs.

\section{Conclusions}

This paper investigates the issue of income convergence or divergence. What factors force income to converge or diverge? While various possible determinants may provoke income converge or diverge, we examine whether financial development may explain income convergence or divergence. To capture the development of the financial sector, we use nine different variables. We also examine whether the economies in our sample converge or diverge in real per capita income as well as investment to GDP. Our sample included 50 countries, broadly distributed in geography and real per capita income.

We find no evidence supporting full convergence of real per capita income for all countries in our sample. Rather, we discover club convergence with six different clubs for real per capita income. In our robustness tests, we uncover three convergence clubs for investment to GDP, while we reject its full convergence for all countries in the sample.

Our results indicate that measures of financial development may offer explanatory power in explaining club convergence for real per capita income and investment to GDP, although different financial development variables prove related to real per capita income and investment to GDP. That is, we find convergence clubs for deposit money banks assets to central bank and deposit money banks assets, deposit money banks assets to GDP, bank deposits to GDP, financial system deposits to GDP, private credit by deposit money banks to GDP, and private credit by deposit money banks and other financial institutions to GDP that show correlation with the convergence clubs for real per capita income. At the same time, we find convergence clubs for deposit money banks assets to GDP, liquid liabilities to GDP, bank deposits to GDP, 
financial system deposits to GDP, private credit by deposit money banks to GDP, and private credit by deposit money banks and other financial institutions to GDP that also show correlation with the convergence clubs for investment to GDP. In addition, the convergence clubs for investment to GDP prove related to the convergence clubs for real per capita income. Those financial development measures that exhibit convergence clubs that are associated with the convergence clubs of real per capita income and investment to GDP generally measure a financial variable relative to GDP. For example, the provision of credit to the economy relative to GDP may offer explanatory power in determining the convergence clubs for real per capita income and investment to GDP.

The above empirical findings agree with the results of Levine and Zervos (1996), who find that the variable "bank loans to private firms divided by GDP" positively correlates with economic growth. Additionally, our results partially agree with the results of Beck et al. (2000), who find that an activity measure of financial intermediation positively correlates with economic growth and agree with those of Aghion et al. (2004), who find that financial development significantly determines income divergence across countries, using as main indicator an activity measure of financial intermediation.

Our results suggest that the quality (how effective is the allocation of funds) of the financial intermediation system of a country and the size of that system relative to GDP are key factors of income convergence or divergence. This general result comes into agreement with that of Levine and Zervos (1996), who use the activity measures of the financial intermediation as the most characteristic variables of the financial system's effectiveness. Future research efforts may include measures relative to the financial markets development (market capitalization, stock market liquidity, bond market developments) and additional qualitative variables, such as, 
accounting standards, institutional or political country characteristics and characteristics of national economic policies (Benhabib and Jovanovic, 1991).

Finally, our findings provide some observations about individual OECD countries. Generally, OECD countries fall into the same convergence clubs. For example, all OECD countries fall into the same club in Tables 2, 5, 9, and 11.Exceptions do occur. Denmark and Finland appear together in convergence clubs that differ from most other OECD countries in Tables 4, 6, 7, and 8. Italy joins Denmark and Finland in Tables 6, 7, and 8 and stands alone in Table 10.Japan falls in the non-convergence club in tables 6,7 , and 8 and in a separate convergence club from other OECD countries in Table 3. 


\section{References}

Aghion, P., Howitt, P., and Mayer-Foulkes, D., (2004). "The Effect of Financial Development on Convergence: Theory and Evidence." NBER Working Paper Series, Working Paper 10358.

Atje, R. and Jovanovic, B., (1993). "Stock Markets and Development." European Economic Review 37, 632-640.

Azariadis, C. and Drazen, A., (1990). "Threshold Externalities in Economic Development". Quarterly Journal of Economics 105, 501-526.

Barro, R., and Sala-i-Martin, X., (1992). "Convergence.” The University of Chicago Press, 100, 223-251.

Beck T., Demirguc-Kant A., and Levine R., (2000). "A New Database on Financial Development and Structure.” World Bank Economic Review 14, 597-605.

Benhabib, J., and Jovanovic, B., (1991). "Externalities and Growth Accounting." American Economic Review 81, 82-113.

Bernard, A. and Durlauf, S., (1996). "Interpreting Tests of the Convergence Hypothesis", Journal of Econometrics 71, 161-173.

Bernard, A., and Durlauf, S., (1995). “Convergence in International Output.” Journal of Applied Econometrics 10, 97-108.

Blanchard, O., and Fischer, S., (1989). Lectures on Macroeconomics. MIT Press: Cambridge, MA.

Blinder, M. and Pesaran, M.H., (1999). "Stochastic Growth Models and their Econometric Implications", Journal of Economic Growth 4, 13-183.

Bliss, C., (2000). “Galton's Fallacy and Economic Convergence: A Reply to Cannon and Duck”, Oxford Economic Papers 52, 420-422.

Bliss, C., (1999). “Galton's Fallacy and Economic Convergence”, Oxford Economic Papers 51, 4-14.

Cannon, E. and Duck, N., (2000). “Galton's Fallacy and Economic Convergence”, Oxford Economic Papers 53, 415-419.

Canova, F., (1999). "Testing For Convergence Clubs in Income Per Capita: A Predictive Density Approach.” International Economic Review 45, 49-77. 
De Long, B., and Summers, L., (1992). "Equipment Investment and Economic Growth: How Strong is the Nexus?" Brookings Papers on Economic Activity, 157-211.

De Long, B., and Summers, L., (1991). "Equipment Investment and Economic Growth." Quarterly Journal of Economics 106, 445-502.

Demetriades, P., and Hussein, K., (1996). "Does Financial Development Cause Economic Growth? Time-Series Evidence from 16 Countries." Journal of Development Economics 51, 387-411.

Doppelhoffer, G., Miller, R., and Sala-i-Martin, X., (2004). "Determinants of Economic Growth: A Bayesian Averaging of Classical Estimates (BACE) Approach." American Economic Review 94, 813-835.

Durlauf, S., and Johnson, P., (1995). "Multiple Regimes and Cross-Country Growth Behavior." Journal of Applied Econometrics 10, 365-384

Durlauf, S.N., Johnson, P.A. and Temple, R.W., (2005). “Growth Econometrics”. In: Aghion, P., Durlauf, S.N. (Eds.), Handbook of Economic Growth, Volume 1. North Holland, Amsterdam.

Easterly, W., and Levine, R., (2001). "It's Not Factor Accumulation: Stylized Facts and Growth Models." World Bank Economic Review 15, 177-219.

Easterly, W., Kremer, M., Pitchett, L., and Summers, L. H., (1993). "Good Policy or Good Luck? Country Growth Performance and Temporary Shocks." Journal of Monetary Economics 32, 459-483.

Evans, P., (1996). "Using Cross Country Variances to Evaluate Growth Theories." Journal of Economic Dynamics and Control 20, 1027-1049.

Friedman, M., (1992). “Do Old Fallacies Die?”, Journal of Economic Literature 30, 2129-2132.

Fung, M., (2008). "Financial Development and Economic Growth: Convergence or Divergence?" Journal of International Money and Finance 28, 56-67.

Friedman, M., (1992). “Do Old Fallacies Ever Die?” Journal of Economic Literature 30, 2129 2032.

Goldsmith, R. W., (1969). Financial Structure and Development. Yale University Press: New Haven, CT.

Grier, K., and Grier, R., (2007). "Only Income Diverges: A Neoclassical Anomaly.” Journal of Development Economics 84, 25-45. 
Hobijn, B. and Frances, P.H., (2000). "Asymptotically Perfect and Relative Convergence of Productivity", Journal of Applied Econometrics 15, 59-81.

Islam, N., (1995). "Growth Empirics: A Panel Data Approach." The Quarterly Journal of Economics 110, 1127-1170.

Jones, C., (1995). “R\&D-Based Models of Economic Growth.”' Journal of Political Economy $103,759-84$.

Jung, W., (1986). "Financial Development and Economic Growth: International Evidence." Economic Development and Cultural Change 34, 333-346.

King, R., and Levine, R., (1993). “Finance, Entrepreneurship, and Growth.” Journal of Monetary Economics 32, 513-542.

Lee, K., Pesaran, H., and Smith, R., (1997). "Growth and Convergence in a Multi-Country Empirical Stochastic Solow Model.” Journal of Applied Econometrics 12, 357-392.

Levine, R., and Zervos, S., (1993). "What we Have Learned about Policy and Growth from Cross-Country Regressions?” The American Economic Review 83, 426-430.

Levine, R., and Renelt, D., (1992). "A Sensitivity Analysis of Cross-Country Growth Regressions.” American Economic Review 82, 942-963.

Levine, R., Loayza, N., and Beck, T., (1999). "Financial Intermediation and Growth: Causality and Causes.” World Bank Policy Research Working Paper, No. 2059.

Lucas, R. E., Jr., (1988). "On the Mechanics of Development Planning." Journal of Monetary Economics 22, 3-42.

Mankiw, G., Romer, D., and Weil, D., (1992). "A Contribution to the Empirics of Economic Growth.” The Quarterly Journal of Economics.107, 407-437.

Patrick, H. T., (1966). "Financial Development and Economic Growth in Underdeveloped Countries." Economic Development and Cultural Change 14, 174-89.

Penn World Tables: 6.2, http://dc1.chass.utoronto.ca/pwt/alphacountries.html

Pesaran, H., (2006). "A Pair-Wise Approach to Testing for Output and Growth Convergence." Journal of Econometrics 138, 312-355.

Phillips, P., and Sul, D., (2007). "Transition Modeling and Econometric Convergence Tests." Econometrica 75, 1771-1855.

Phillips, P.C.B. and Sul, D., (2003). "The Elusive Empirical Shadow of Growth Convergence”, Cowles Discussion Paper \#1398, Yale University. 
Quah, D., (1993). "Galton's Fallacy and Tests of the Convergence Hypothesis." The Scandinavian Journal of Economics 95, 427-443.

Quah, D., (1996). "Twin Peaks: Growth and Convergence in Models of Distribution Dynamics." The Economic Journal 106, 1045-1055.

Quah, D., (1997). "Empirics for Growth and Distribution: Polarization, Stratification and Convergence Club." Journal of Economic Growth 2, 27-59.

Rajan, R., and Zingales, L., (1998). "Financial Dependence and Growth. The American Economic Review 88, 559-586.

Rodrik, D., (1994). "Getting Interventions Right: How South Korea and Taiwan Grew Rich." NBER Working Paper, No. 4964.

Romer, P., (1986). "Increasing Returns and Long-Run Growth." Journal of Political Economy 94, 1002-1037.

Solow, R., (1956). "A Contribution to the Theory of Economic Growth." Quarterly Journal of Economics 70, 65-94.

Swan, T. W., (1956). "Economic Growth and Capital Accumulation.” Economic Record 32, 334361.

Uzawa, H., (1996). "An Endogenous Rate of Time Preference, the Penrose Effect and Dynamic Optimality of Environmental Quality." Proceedings of the National Academy of Sciences of the United States of America 93, 5770-5776.

World Bank's Financial Development and Structure database: http://econ.worldbank.org/WBSITE/EXTERNAL/EXTDEC/EXTRESEARCH/0, contentM DK:20696167 pagePK:64214825 piPK:64214943 theSitePK:469382,00.html 


\section{Appendix A}

The sample includes the following countries:

\begin{tabular}{|c|c|c|c|c|}
\hline Algeria & Australia & Burundi & Cameroon & Canada \\
\hline Chile & $\begin{array}{l}\text { Costa } \\
\text { Rica }\end{array}$ & $\begin{array}{c}\text { Cote } \\
\text { d’Ivoire }\end{array}$ & Denmark & Dominica \\
\hline $\begin{array}{l}\text { Dominican } \\
\text { Republic }\end{array}$ & Ecuador & Egypt & $\begin{array}{c}\text { El } \\
\text { Salvador }\end{array}$ & Finland \\
\hline Grenada & Guatemala & Honduras & India & Italy \\
\hline Jamaica & Japan & Jordan & Kenya & $\begin{array}{c}\text { Korea, } \\
\text { Republic of }\end{array}$ \\
\hline Madagascar & Malaysia & Mauritius & Nepal & $\begin{array}{c}\text { New } \\
\text { Zealand }\end{array}$ \\
\hline Niger & Nigeria & Pakistan & $\begin{array}{l}\text { Papua New } \\
\text { Guinea }\end{array}$ & Paraguay \\
\hline Philippines & Portugal & Senegal & Spain & $\begin{array}{c}\text { Sri } \\
\text { Lanka }\end{array}$ \\
\hline $\begin{array}{l}\text { St. Vincent and } \\
\text { the Grenadines }\end{array}$ & Suriname & Switzerland & Thailand & Togo \\
\hline $\begin{array}{c}\text { Trinidad \& } \\
\text { Tobago }\end{array}$ & $\begin{array}{c}\text { United } \\
\text { Kingdom }\end{array}$ & $\begin{array}{l}\text { United } \\
\text { States }\end{array}$ & Uruguay & Venezuela \\
\hline
\end{tabular}

\section{Appendix B}

The term 'Other Financial Institutions' involves the following institutions:

- institutions that accept deposits, but do not provide transferable deposit facilities

- intermediaries that finance themselves mainly through issuance of negotiable bonds

- development banks

- offshore units

- insurance companies

- provident and pension funds

- trust and custody accounts

- real investments schemes

- other pooled investment schemes

- compulsory savings schemes 
Table 1: $\quad$ Club Convergence: Per Capita GDP

\begin{tabular}{|c|c|c|c|}
\hline Subgroup & Countries & t-statistic & b coefficient \\
\hline Full sample & & -288.270 & -0.904 \\
\hline $\mathbf{1}^{\text {st }}$ subgroup & $\begin{array}{c}\text { Australia, Canada, Denmark, Finland, Italy, Japan, Korea, } \\
\text { Malaysia, Mauritius, Portugal, Spain, St. Vincent and the } \\
\text { Grenadines, Switzerland, Thailand, UK }\end{array}$ & 3.974 & 0.276 \\
\hline $\mathbf{2}^{\text {nd }}$ subgroup & $\begin{array}{c}\text { Chile, Costa Rica, Dominica, Dominican Republic, New } \\
\text { Zealand, Sri Lanka, Trinidad and Tobago, Uruguay }\end{array}$ & -0.677 & -0.019 \\
\hline $\mathbf{3}^{\text {rd }}$ subgroup & $\begin{array}{c}\text { Algeria, Ecuador, Egypt, El Salvador, Grenada, } \\
\text { Guatemala, India, Jamaica, Jordan, Pakistan, Papua-New } \\
\text { Guinea, Paraguay, Philippines, Suriname, Venezuela }\end{array}$ & 3.542 & 0.248 \\
\hline $\mathbf{4}^{\text {th }}$ subgroup & Cameroon, Cote d'Ivoir, Honduras, Nepal, Senegal & 1.452 & 0.245 \\
\hline $\mathbf{5}^{\text {th }}$ subgroup & Burundi, Madagascar, Niger, Togo & 4.587 & 2.052 \\
\hline Non - converging & Kenya, Nigeria, US & -57.680 & -0.899 \\
\hline
\end{tabular}

Table 2: $\quad$ Club Convergence: Deposit Money Banks Assets to Central Bank and Deposit Money Banks Assets

\begin{tabular}{|c|c|c|c|}
\hline Subgroup & Countries & t-statistic & b coefficient \\
\hline Full sample & & -2.127 & -0.215 \\
\hline $\mathbf{1}^{\text {st }}$ subgroup & $\begin{array}{c}\text { Algeria, Australia, Burundi, Canada, Chile, Costa Rica, } \\
\text { Denmark, Dominica, Dominican Republic, Ecuador, } \\
\text { Egypt, El Salvador, Finland, Grenada, Guatemala, } \\
\text { Honduras, India, Italy, Jamaica, Japan, Jordan, Kenya, } \\
\text { Korea, Madagascar, Malaysia, Mauritius, New Zealand, } \\
\text { Pakistan, Papua-New Guinea, Paraguay, Philippines, } \\
\text { Portugal, Spain, Sri Lanka, St. Vincent and the } \\
\text { Grenadines, Suriname, Switzerland, Thailand, Trinidad } \\
\text { and Tobago, UK, US, Uruguay, Venezuela }\end{array}$ & 2.053 & 0.330 \\
& Cote d'Ivoir, Nepal, Nigeria, Senegal, Togo & & \\
\hline $\mathbf{2}^{\text {nd }}$ subgroup & Cameroon, Niger & 1.287 & \\
\hline Non - converging & & -15.968 & -2.408 \\
\hline
\end{tabular}

Table 3: $\quad$ Club Convergence: Bank Credit to Bank Deposits

\begin{tabular}{|c|c|c|c|}
\hline Subgroup & Countries & t-statistic & b coefficient \\
\hline Full sample & Australia, Burundi, Cameroon, Canada, Chile, Costa Rica, \\
\hline $\mathbf{1}^{\text {st }}$ subgroup & $\begin{array}{c}\text { Cote d Ivoir, Denmark, Dominica, Dominican Republic, } \\
\text { Ecuador, Egypt, El Salvador, Finland, Grenada, } \\
\text { Guatemala, Honduras, Italy, Jordan, Kenya, Korea, } \\
\text { Malaysia, Mauritius, Nepal, New Zealand, Nigeria, } \\
\text { Paraguay, Portugal, Senegal, Spain, Sri Lanka, St. Vincent } \\
\text { and the Grenadines, Switzerland, Thailand, Togo, UK, US, } \\
\text { Uruguay }\end{array}$ & -1.603 & -0.824 \\
\hline $\mathbf{2}^{\text {nd }}$ subgroup & $\begin{array}{c}\text { India, Jamaica, Japan, Madagascar, Niger, Pakistan, } \\
\text { Papua-New Guinea, Philippines, Suriname, Trinidad and } \\
\text { Tobago, Venezuela }\end{array}$ & 3.808 & \\
\hline Non - converging & Algeria & - & 0.401 \\
\hline
\end{tabular}


Table 4: Club Convergence: Central Bank Assets to GDP

\begin{tabular}{|c|c|c|c|}
\hline Subgroup & Countries & t-statistic & b coefficient \\
\hline Full sample & & -2.904 & -0.380 \\
\hline $1^{\text {st }}$ subgroup & $\begin{array}{c}\text { Australia, Burundi, Cameroon, Canada, Chile, Cote } \\
\text { d'Ivoir, Egypt, Guatemala, India, Italy, Jamaica, Japan, } \\
\text { Jordan, Kenya, Korea, Malaysia, Nepal, New Zealand, } \\
\text { Niger, Nigeria, Pakistan, Papua-New Guinea, Paraguay, } \\
\text { Philippines, Senegal, St. Vincent and the Grenadines, } \\
\text { Switzerland, Thailand, Togo, UK, US, Uruguay, } \\
\text { Venezuela }\end{array}$ & -1.555 & -0.173 \\
\hline $2^{\text {nd }}$ subgroup & $\begin{array}{l}\text { Algeria, Costa Rica, Denmark, Dominica, Dominican } \\
\text { Republic, Ecuador, El Salvador, Finland, Grenada, } \\
\text { Honduras, Madagascar, Mauritius, Portugal, Spain, Sri } \\
\text { Lanka, Suriname, Trinidad and Tobago }\end{array}$ & -0.709 & -0.145 \\
\hline
\end{tabular}

Table 5. Club Convergence: Deposit Money Banks Assets to GDP

\begin{tabular}{|c|c|c|c|}
\hline Subgroup & Countries & t-statistic & b coefficient \\
\hline Full sample & & -0.371 & -0.026 \\
\hline $1^{\text {st }}$ subgroup & $\begin{array}{c}\text { Australia, Burundi, Canada, Chile, Costa Rica, Denmark, } \\
\text { Dominica, Ecuador, Egypt, El Salvador, Finland, Grenada, } \\
\text { Honduras, India, Italy, Jamaica, Japan, Jordan, Kenya, } \\
\text { Korea, Malaysia, Mauritius, New Zealand, Pakistan, } \\
\text { Paraguay, Philippines, Portugal, Spain, Sri Lanka, St. } \\
\text { Vincent and the Grenadines, Switzerland, Thailand, UK, } \\
\text { US, Uruguay }\end{array}$ & -1.581 & -0.148 \\
\hline $2^{\text {nd }}$ subgroup & $\begin{array}{c}\text { Algeria, Cote d Ivoir, Dominican Republic, Guatemala, } \\
\text { Madagascar, Nepal, Nigeria, Papua-New Guinea, Senegal, } \\
\text { Togo, Trinidad and Tobago }\end{array}$ & 0.659 & 0.038 \\
\hline $3^{\text {rd }}$ subgroup & Cameroon, Suriname, Venezuela & 1.232 & 0.238 \\
\hline Non - converging & Niger & - & - \\
\hline
\end{tabular}

Table 6: $\quad$ Club Convergence: Liquid Liabilities to GDP

\begin{tabular}{|c|c|c|c|}
\hline Subgroup & Countries & t-statistic & b coefficient \\
\hline Full sample & Australia, Canada, Chile, Dominica, Egypt, Grenada, \\
\hline $\mathbf{1}^{\text {st }}$ subgroup & $\begin{array}{c}\text { Honduras, India, Jordan, Korea, Malaysia, Mauritius, } \\
\text { Nepal, New Zealand, Philippines, Portugal, Spain, St. } \\
\text { Vincent and the Grenadines, Switzerland, Thailand, UK, } \\
\text { US, Uruguay }\end{array}$ & -0.973 & -0.989 \\
\hline $\mathbf{2}^{\text {nd }}$ subgroup & $\begin{array}{c}\text { Denmark, Dominican Republic, El Salvador, Finland, } \\
\text { Italy, Jamaica, Pakistan, Sri Lanka, Trinidad and Tobago }\end{array}$ & 2.970 & 0.439 \\
\hline $\mathbf{3}^{\text {rd }}$ subgroup & $\begin{array}{c}\text { Algeria, Burundi, Cameroon, Costa Rica, Cote d'Ivoir, } \\
\text { Ecuador, Guatemala, Kenya, Madagascar, Niger, Nigeria, } \\
\text { Papua-New Guinea, Paraguay, Senegal, Suriname, Togo, } \\
\text { Venezuela }\end{array}$ & 5.829 & 0.509 \\
\hline Non - converging & Japan & - & - \\
\hline
\end{tabular}


Table 7: $\quad$ Club Convergence: Bank Deposits to GDP

\begin{tabular}{|c|c|c|c|}
\hline Subgroup & Countries & t-statistic & b coefficient \\
\hline Full sample & & -49.520 & -0.893 \\
\hline $1^{\text {st }}$ subgroup & Canada, Malaysia, Switzerland & 2.317 & 2.154 \\
\hline $2^{\text {nd }}$ subgroup & $\begin{array}{c}\text { Australia, Chile, Dominica, Egypt, Grenada, Honduras, } \\
\text { Jordan, Korea, Mauritius, New Zealand, Philippines, } \\
\text { Portugal, Spain, St. Vincent and the Grenadines, Thailand, } \\
\text { UK, US }\end{array}$ & 1.354 & 0.058 \\
\hline $3^{\text {rd }}$ subgroup & $\begin{array}{l}\text { Burundi, Costa Rica, Denmark, Dominican Republic, } \\
\text { Ecuador, El Salvador, Finland, India, Italy, Jamaica, } \\
\text { Kenya, Nepal, Pakistan, Papua-New Guinea, Paraguay, Sri } \\
\text { Lanka, Trinidad and Tobago, Uruguay }\end{array}$ & 1.148 & 0.124 \\
\hline $4^{\text {th }}$ subgroup & $\begin{array}{l}\text { Algeria, Cameroon, Cote d Ivoir, Guatemala, Madagascar, } \\
\text { Niger, Nigeria, Senegal, Suriname, Togo, Venezuela }\end{array}$ & 2.387 & 0.234 \\
\hline Non - converging & Japan & - & - \\
\hline
\end{tabular}

Table 8: Club Convergence: Financial System Deposits to GDP

\begin{tabular}{|c|c|c|c|}
\hline Subgroup & Countries & t-statistic & b coefficient \\
\hline Full sample & & -52.154 & -0.932 \\
\hline $\mathbf{1}^{\text {st }}$ subgroup & $\begin{array}{c}\text { Australia, Canada, Chile, Dominica, Egypt, Grenada, } \\
\text { Honduras, Jordan, Korea, Malaysia, Mauritius, New } \\
\text { Zealand, Philippines, Portugal, Spain, St. Vincent and the } \\
\text { Grenadines, Switzerland, Thailand, UK, US }\end{array}$ & -0.593 & -0.021 \\
\hline $\mathbf{2}^{\text {nd }}$ subgroup & $\begin{array}{c}\text { Algeria, Burundi, Costa Rica, Denmark, Dominican } \\
\text { Republic, Ecuador, El Salvador, Finland, Guatemala, } \\
\text { India, Italy, Jamaica, Kenya, Madagascar, Nepal, Nigeria, } \\
\text { Pakistan, Papua-New Guinea, Paraguay, Senegal, Sri } \\
\text { Lanka, Suriname, Trinidad and Tobago, Uruguay }\end{array}$ & -0.932 & -0.071 \\
\hline $\mathbf{3}^{\text {rd }}$ subgroup & Cameroon, Cote d'Ivoir, Niger, Togo, Venezuela & 0.795 & 0.021 \\
\hline Non - converging & Japan & - & - \\
\hline
\end{tabular}

Table 9: Club Convergence: Private Credit by Deposit Money Banks to GDP

\begin{tabular}{|c|c|c|c|}
\hline Subgroup & Countries & t-stat & b coefficient \\
\hline Full sample & & -15.756 & -0.870 \\
\hline $\mathbf{1}^{\mathbf{s}}$ subgroup & $\begin{array}{c}\text { Australia, Burundi, Canada, Chile, Costa Rica, Denmark, } \\
\text { Dominica, Dominican Republic, Egypt, El Salvador, } \\
\text { Finland, Grenada, Honduras, Italy, Japan, Jordan, Korea, } \\
\text { Malaysia, Mauritius, Nepal, New Zealand, Paraguay, } \\
\text { Philippines, Portugal, Spain, Sri Lanka, St Vincent and the } \\
\text { Grenadines, Switzerland, Thailand, UK, US, Uruguay }\end{array}$ & -1.301 & -0.130 \\
\hline $\mathbf{2}^{\text {nd }}$ subgroup & $\begin{array}{c}\text { Ecuador, Guatemala, India, Jamaica, Kenya, Pakistan, } \\
\text { Trinidad and Tobago }\end{array}$ & 1.768 & 0.305 \\
\hline $\mathbf{3}^{\text {rd }}$ subgroup & $\begin{array}{c}\text { Cote d'Ivoir, Nigeria, Papua New Guinea, Senegal, } \\
\text { Suriname, Togo }\end{array}$ & 4.565 & 1.343 \\
\hline $\mathbf{4}^{\text {th }}$ subgroup & Algeria, Cameroon, Madagascar, Niger, Venezuela & 3.498 & 0.789 \\
\hline
\end{tabular}


Table 10: Club Convergence: Private Credit by Deposit Money Banks and other Financial Institutions to GDP

\begin{tabular}{|c|c|c|c|}
\hline Subgroup & Countries & t-statistic & b coefficient \\
\hline Full sample & & -34.568 & -1.114 \\
\hline $1^{\text {st }}$ subgroup & $\begin{array}{c}\text { Australia, Canada, Chile, Denmark, Dominica, Egypt, } \\
\text { Grenada, Italy, Japan, Jordan, Korea, Malaysia, Mauritius, } \\
\text { New Zealand, Portugal, Spain, St Vincent, Switzerland, } \\
\text { Thailand, UK, US }\end{array}$ & -1.309 & -0.115 \\
\hline $2^{\text {nd }}$ subgroup & $\begin{array}{c}\text { Burundi, Costa Rica, Dominican Rep, Ecuador, El } \\
\text { Salvador, Finland, Guatemala, Honduras, India, Nepal, } \\
\text { Paraguay, Philippines, Sri Lanka, Trinidad and Tobago, } \\
\text { Uruguay }\end{array}$ & 1.404 & 0.350 \\
\hline $3^{\text {rd }}$ subgroup & Kenya, Pakistan & -1.455 & -0.105 \\
\hline $4^{\text {th }}$ subgroup & $\begin{array}{c}\text { Cote d'Ivoir, Jamaica, Nigeria, Papua New Guinea, } \\
\text { Senegal }\end{array}$ & 0.856 & 0.087 \\
\hline $5^{\text {th }}$ subgroup & Madagascar, Suriname, Togo, Venezuela & 0.150 & 0.011 \\
\hline $6^{\text {th }}$ subgroup & Algeria, Cameroon, Niger & 6.256 & 0.803 \\
\hline
\end{tabular}

Table 11: Club Convergence: Fixed Capital Investments to GDP

\begin{tabular}{|l|c|c|c|}
\hline Group & Countries & t-statistic & b coefficient \\
\hline Full Sample & \multicolumn{1}{|c|}{. } & -33.663 & -1.073 \\
\hline $\mathbf{1}^{\text {st }}$ subgroup & $\begin{array}{c}\text { Australia, Canada, Chile, Denmark, Dominican Republic, } \\
\text { Ecuador, Finland, Grenada, Honduras, India, Italy, } \\
\text { Jamaica, Japan, Korea, Malaysia, Nepal, New Zealand, } \\
\text { Philippines, Portugal, Spain, Suriname, Switzerland, } \\
\text { Thailand, Trinidad and Tobago, UK, US }\end{array}$ & -1.246 & -0.108 \\
\hline $\mathbf{2}^{\text {nd }}$ subgroup & $\begin{array}{c}\text { Algeria, Costa Rica, Dominica, El Salvador, Jordan, } \\
\text { Kenya, Mauritius, Niger, Pakistan, Papua-New Guinea, } \\
\text { Paraguay, Senegal, Sri Lanka, St. Vincent and the } \\
\text { Grenadines, Togo, Uruguay, Venezuela }\end{array}$ & 3.622 & 0.545 \\
\hline $\mathbf{3}^{\text {rd }}$ subgroup & $\begin{array}{c}\text { Burundi, Cameroon, Cote d'Ivoir, Egypt, Guatemala, } \\
\text { Madagascar, Nigeria, }\end{array}$ & 4.617 & 0.287 \\
\hline
\end{tabular}


Table 12: Chi-Squared Statistics for Independence

\begin{tabular}{|c|c|c|c|c|}
\hline Second Variable & $\begin{array}{c}\text { DF } \\
(\mathrm{c}-1)(\mathrm{r}-1)\end{array}$ & $\begin{array}{l}\text { Real GDP } \\
\text { per capita }\end{array}$ & $\begin{array}{c}\text { DF } \\
(\mathrm{c}-1)(\mathrm{r}-1)\end{array}$ & $\begin{array}{l}\text { Investment } \\
\text { to GDP }\end{array}$ \\
\hline $\begin{array}{l}\text { Deposit Money Banks Assets to } \\
\text { Central Bank and Deposit Money } \\
\text { Banks Assets }\end{array}$ & $2 * 5=10$ & $32.22 * * *$ & $2 * 2=4$ & 7.51 \\
\hline Bank Credit to Bank Deposits & $2 * 5=10$ & 14.99 & $2 * 2=4$ & 2.32 \\
\hline Central Bank Assets to GDP & $1 * 5=5$ & 5.03 & $1 * 2=2$ & 1.46 \\
\hline Deposit Money Banks Assets to GDP & $3 * 5=15$ & $29.45^{* *}$ & $3 * 2=6$ & $10.76^{*}$ \\
\hline Liquid Liabilities to GDP & $3 * 5=15$ & 20.25 & $3 * 2=6$ & $22.26^{* * *}$ \\
\hline Bank Deposits to GDP & $4 * 5=20$ & $29.42 *$ & $4 * 2=8$ & $17.55^{* *}$ \\
\hline Financial System Deposits to GDP & $3 * 5=15$ & $27.16^{* *}$ & $3 * 2=6$ & $12.31^{*}$ \\
\hline $\begin{array}{l}\text { Private Credit by Deposit Money } \\
\text { Banks to GDP }\end{array}$ & $3 * 5=15$ & $32.51 * * *$ & $3 * 2=6$ & $12.44^{*}$ \\
\hline $\begin{array}{l}\text { Private Credit by Deposit Money } \\
\text { Banks and other Financial } \\
\text { Institutions to GDP }\end{array}$ & $5 * 5=25$ & $56.60 * * *$ & $5 * 2=10$ & $16.88^{*}$ \\
\hline Fixed Capital Investments to GDP & $2 * 5=10$ & $20.23^{* *}$ & $2 * 2=4$ & \\
\hline
\end{tabular}

\footnotetext{
Note: Categorical variables included in the tests of independence equal the convergence clubs for real GDP per capita or investment to GDP and for one of the other variables.

*** $\quad$ significant at the 1-percent level

** $\quad$ significant at the 5-percent level

* $\quad$ significant at the 10 -percent level
} 